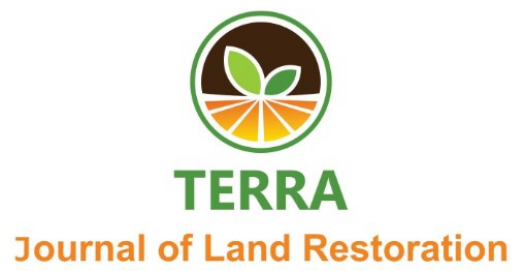

\title{
Land Suitability Evaluation for New Paddy Rice Field in Mukomuko District
}

\author{
Albert Carles $^{1}$, Kanang Setyo Hindarto ${ }^{1 *}$, Heru Widiyono ${ }^{1}$, Mukhtasar $^{2}$, Hermansyah $^{2}$ \\ ${ }^{1}$ Soil Science Department, University of Bengkulu, Bengkulu, 38121, Indonesia \\ ${ }^{2}$ Agroecotechnology Department, University of Bengkulu, Bengkulu, 38121, Indonesia
}

e-mail:

\begin{abstract}
This study aims to identify the physical, chemical characteristics of the soil and determine the suitability of rice fields for new openings in Mukomuko. This research was conducted from September to October 2019, which consisted of fieldwork and laboratory analysis. This research uses a survey method, soil sampling is carried out by a composite method consisting of 5 soil samples. Composite soil sampling technique based on land unit work maps produced from the map of soil types Mukomuko district scale of 1: 100.000. The results showed that all samples had the same dominant limiting factors namely $\mathrm{P}_{2} \mathrm{O}_{5}, \mathrm{~K}_{2} \mathrm{O}$, and Base Saturation. Land suitability for lowland rice plants in Mukomuko District Af.1.2.1 (S3nr) land area with an area of 42.68 ha, Af.1.2.2 (S3nr) land area with an area of 56.65 ha, land unit Tf.2.1 (S3nr) with an area of 60.15 ha, and land unit Tf.3.1 (S3nr) with an area of 89.30 ha.
\end{abstract}

Keywords: Paddy Rice Crops, Land Suitability, Potential for Rice Field Expansion.

\section{INTRODUCTION}

The food needs of the people in Indonesia amounting to $96.09 \%$ are obtained from consuming rice, thus the aspect of the food crop farming business system is very necessary. This is in order to get a more detailed picture of the business of lowland rice farmers as rice producers, which greatly affects food availability in Indonesia. Rice farming is related to two things, namely in terms of revenue and in terms of financing. Farming cost components generally consist of production facilities costs, labor wages and other costs (Arsyad \& Rustiadi, 2008).

Several important reasons need to increase rice production in a sustainable manner. This is given that rice is a staple food material for the people of Indonesia, and is an important commodity to maintain food security. Rice farming is already a part of life for Indonesian farmers so that it creates large employment opportunities and the contribution of rice farming to household income is quite large (Hamdan, 2013).

Increasing rice production in Indonesia can be done by intensification and extension. Intensification of agriculture is one of the efforts to increase agricultural yields by optimi- zing existing agricultural land. Agricultural intensification commonly considered is the problem of seed procurement, soil processing, planting, fertilization, eradication of pests and diseases, harvesting, and post-harvest activities (Badan Penyuluh Pertanian, 2012).

Agricultural extension is the expansion of land by finding new land that can be planted and produce crops that can meet the food needs of the community, can be done independently, sustainably, and get full supervision from the government. One of them is by moving the transmigration program, there are several kinds of extension, namely, expansion of agricultural land with forest land clearing, land expansion with dry land clearing, expansion of agricultural land with peatland clearing (Badan Penyuluh Pertanian, 2012).

The availability of food, especially rice, is an important issue in agricultural development. This is a leading indicator in realizing national

food security or food sovereignty. Therefore, increased production (in this case rice fields) is the main thing that concerns the Indonesian government. According to Subejo et al. (2014), The issue of food is the question of the death of a nation. What if society is not independent 
in the field of food, this nation will easily depend on other nations. These concerns have been responded to by the Indonesian government with various programs to increase food production to support the realization of food security. Increased production can be achieved through intensification strategies (both using technological innovation, and social innovation), extension, and diversification (Mardikanto, 2007).

The area of Mukomuko Regency is 403,670 ha or $4,036.7 \mathrm{~km}^{2}$ and the area of the sea along the west coast of Sumatra, with a beach length of about $\pm 98.2 \mathrm{~km}$, is 72,760 ha or $727.60 \mathrm{~km}^{2}$ (calculated as far as 4 miles from the shoreline) (BPS Kabupaten Mukomuko, 2013). Mukomuko irrigation area is divided into the left Mukomuko irrigation area $(6,411 \mathrm{ha})$ which has been inaugurated its use on July 1, 1989 by the President of the Republic of Indonesia Suharto and the right Mukomuko irrigation area $(5,568 \mathrm{ha})$ whose construction has begun since 1997. Mukomuko irrigation area serves a potential area of 11,979 ha which includes rice paddy fields. The source of irrigation water comes from the Manjunto River. Manjunto Water Irrigation Area with a total irrigation area of 11,979 ha with an intake plan discharge of $10.13 \mathrm{~m}^{3}$ seconds $\mathrm{s}^{-1}$. As a result of land transfer, the intake discharge is not as planned, as a result there are some plots of rice fields at the end threatened not to get water so it can cause crop failure (DPU Balai Wilayah Sungai Sumatera VII, 2013).

\section{MATERIALS AND METHODS}

This research has been conducted from September to October 2019, consisting of field activities and laboratory analysis. Field activities include soil sampling located in Tanjung Alai village, Arah Tiga village in Lubuk Pinang Subdistrict, Manjuto Jaya village, Tirta Mulya Village, Manjuto Water District and Pauh Terenja Village XIV Koto Subdistrict. Astronomically Mukomuko Regency is located at coordinates $02-0162^{\prime}$ " to 03007'46" South Latitude (LS) and 101001'15.1" to 101051'29.6" East Longitude (BT). Laboratory analysis includes soil sample analysis activities taken from the field and carried out by the Soil Science Laboratory of the University of Bengkulu.

The tools used in this research are laptop, GPS (Global Positioning System), ArcMap software v10.5, Global Mapper v18, SAS Planet, Google Earth, stationery, airy knife to take soil samples, plastic, rubber band, meter, drill ground.

The materials used in this research are RBI map scale 1: 50,000 as a basic map, land type map scale 1: 100,000 on sheet 0813 , annual rainfall data in the last five years, and information on land harmony class for rice paddy plants.

Soil sampling is taken randomly with a depth of 0 $20 \mathrm{~cm}$ on each unit of land based on the observation area. Each random sample was taken as much as $2 \mathrm{~kg}$. The number of points taken on each unit of land as much as four points, then the sample is composted into one soil sample that is analyzed to represent a unit of observation land with a soil weight of $2 \mathrm{~kg}$.

The next stage is to look at the availability of nutrients on the land of new paddy printing plans such as $\mathrm{pH}, \mathrm{C}$-organic, texture, saturation bases, CEC, N, P, K, and salinity. Social data retrieval techniques in the field can interview farmers. The last stage is the output in the form of a unit of land suitability map.

Field data and laboratory analysis results are correlated so that the process of evaluation and assessment of land suitability can be carried out. The data are grouped by each land quality based on a method developed by the FAO (1967). Fao system land conformity class determination method (1967) using 4 class categories and 6 sub-classes. Land conformity class consists of S1 (very suitable), S2 (quite appropriate), S3 (marginally appropriate), N (not appropriate). Sub-classes are based on limiting factors such as land characteristics such as climate (tc), root media (rc), nutrient retention (r), nutrient availability (n), and landslide haz$\operatorname{ards}(\mathrm{eh})$.

Furthermore, the data obtained from correlations are interpreted in the form of land suitability maps and management recommendations to overcome the limiting factors of each class of land suitability.

Climate variables observed include average rainfall over the past 5 years, air temperature, and humidity. Drainage is observed directly in the field based on rocks on the surface, where drainage soil is good at ground conditions with rocks. Textures are defined using a method (Hydrometer). Soil depth is measured using a meter at a maximum depth of 2 meters when sampling in the field (Intara et al., 2011).

CEC soil is extracted with Ammonium Acetate $1 \mathrm{~N} \mathrm{pH7}$. Soil $\mathrm{pH}$ is measured using ( $\mathrm{pH}$ meter), with a ratio of aquadest and soil 1:2,5 conducted in the laboratory of Soil Science, Faculty of Agriculture, University of Bengkulu (Sulaeman et al., 2005). N total is defined by method (Kjeldahl). $\mathrm{P}_{2} \mathrm{O}_{5}$ was analyzed by method (Bray I). $\mathrm{K}_{2} \mathrm{O}$ in analysis using methods (Flame-photometer) (Sulaeman et al., 2005). The slope level of the land at the research site was conducted using a clinometer and expressed in percent $(\%)$. 


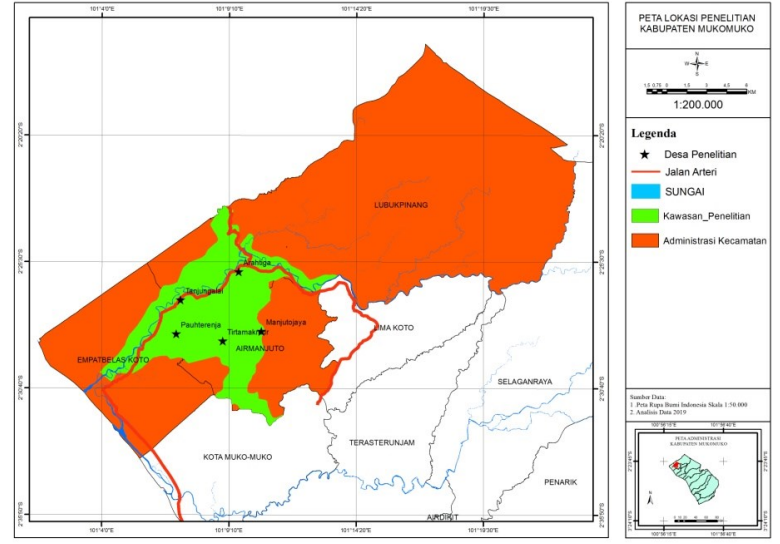

Figure 2. Research site map

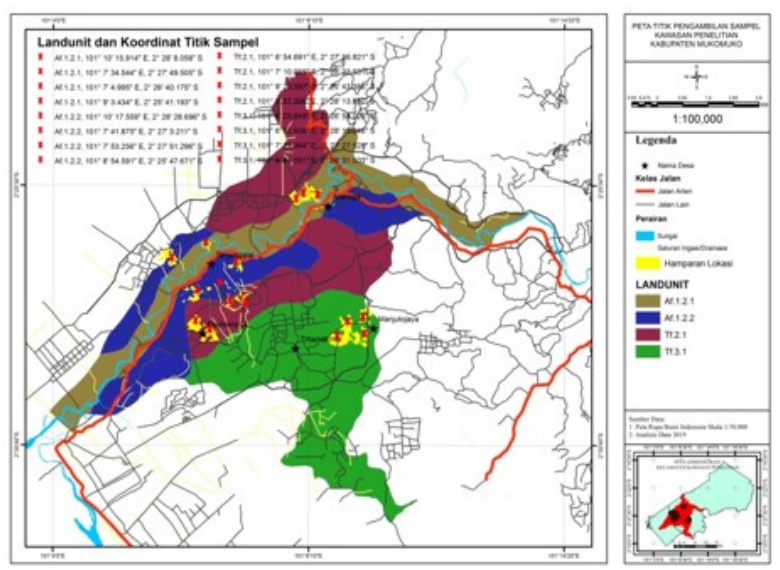

Figure 3. Sampling point map

\section{RESULTS AND DISCUSSION}

Mukomuko District with the capital Mukomuko, located in the northernmost part of Bengkulu Province with a distance of $246.1 \mathrm{~km}$ from the provincial capital, geographically Mukomuko Regency is located at $101^{\circ}$ $01^{\prime} 15.1^{\prime \prime}$ - $101^{\circ} 51 ' 29.6^{\prime \prime}$ east longitude and at $02^{\circ}$ 1632.0" - 03o 07'46.0" south latitude. The air temperature of Mukomuko city ranges from $21.10{ }^{\circ} \mathrm{C}$ to 34.60 ${ }^{\circ} \mathrm{C}$. The boundary of Mukomuko regency in the north is bordered by South Coastal Regency, the south is bordered by North Bengkulu Regency, the west is bordered by the Indian Ocean, the east is bordered by Kerinci Regency, the area of Mukomuko Regency reaches about 4,036.70 kilometers.

Administratively the research site is located in Lubuk Pinang Kecematan, Manjuto Water District, and XIV Koto Subdistrict, where Lubuk Pinang Subdistrict with an area of $92.71 \mathrm{~km}^{2}$, Manjuto Water District with an area of $12.29 \mathrm{~km}^{2}$, and XIV Koto Subdistrict with an area of $77.00 \mathrm{~km}^{2}$ (Seretariat LPPD, 2014).

Based on BMKG data obtained the rainfall of Mukomuko Regency in the last 5 years (2014-2018) is
3,248 $\mathrm{mm}$ year $^{-1}$. According to the criteria of land suitability for rice paddy irrigation by Djaenudin et al. (2011), that the rainfall needed for rice paddy irrigation plants is $>1500 \mathrm{~mm}_{\text {year }}^{-1}$. The rainfall in Mukomuko Regency is 3,248 mm year ${ }^{-1}$ classified as S1/very suitable $\left(>1500 \mathrm{~mm}\right.$ year $\left.{ }^{-1}\right)$. Mukomuko District air temperature data in the last 5 years $(2014-2018)$ is $26^{\circ} \mathrm{C}$.

Criteria for land suitability for rice paddy according to Djaenudin et al., (2011), that the average air temperature required for rice paddy irrigation plants is $24-290 \mathrm{C}$. Therefore, the average air temperature in Mukomuko Regency is $26^{\circ} \mathrm{C}$ classified as S1 or very suitable (24$29^{\circ} \mathrm{C}$ ). Data on humidity in Mukomuko Regency in the last 5 years (2014-2018) averaged 83\%. According to the criteria of land suitability for rice paddy irrigation by Djaenudin et al. (2011), that the humidity needed for rice paddy irrigation plants is $33-90 \%$, so the average humidity in Mukomuko District is $83 \%$ classified as S1 tau very appropriate (33-90\%).

From the observations in the field obtained that the slope conditions in all research areas mukomuko district is relatively flat $0-3 \%$ with an area of 15914.19 ha (100\%). According to Hardjowigeno \&Widiatmaka (2007) the distribution of slopes suitable for the development of rice paddy plants is a slope of $0-15 \%$ with a flat to wavy shape. The physical problem of land for unsuitable areas can be solved by technology such as by the manufacture of terraces, as long as the technology is safe to use for the environment and the costs are still ra-

Table 1. Distribution of Land Units and Study Area Overlay

\begin{tabular}{llcc}
\hline \multirow{2}{*}{ Land Unit } & \multirow{2}{*}{ Village } & \multicolumn{2}{c}{ Wide Expanse } \\
\cline { 3 - 4 } & & ha & $\%$ \\
\hline Af.1.2.1 & Arah Tiga & 42,68 & 17,16 \\
Af.1.2.2 & Tanjung Alai & 56,65 & 22,77 \\
Tf.2.1 & Pauh Terenja & 60,15 & 24,18 \\
& Manjuto Jaya & 36,17 & 14,54 \\
Tf.3.1 & Tirta Makmur & 53,13 & 21,36 \\
\hline \multicolumn{3}{c}{248,78} & 100,00 \\
\hline \multicolumn{2}{c}{ Tond Lnit Map (Bengkulu) scale 1:250.000 and Field Survey }
\end{tabular}

tional.

There are 4 land units in the research location, namely Af 1.2.1 which is a floodplain from a winding river, smooth sediment, tortuous layers, embankments, sewers, with slope class from flat to undulating (slope $<3 \%$ ). ) with a stretch in the Arah Tiga Village which has an area of $42.68 \mathrm{ha}(17.16 \%)$, Af 1.2.2 is a winding river floodplain, fine sediment, swamp, with flat landforms (slopes $<3 \%$ ). The expanse in Tanjung Alai Village which has an area of 56.65 ha $(22.75 \%)$, Tf 2.1 is a sea terrace, fine felsic sedimentary rock, flat (3-8\% slope). The expanse in Pauh Terenja Village which has an area of 60.15 ha $(24.18 \%)$, Tf 3.1 is a sea terrace, fine felsic sedimentary rock, flat ( $3 \%$ slope). Two stretches are in 
the village of Muntungo Jaya with an area of 36.17 hectares $(14.54 \%)$, and a stretch in the village of Tirta Makmur with an area of 53.13 hectares (21.36\%). The distribution of land units in the study area can be seen in Table 1.

Table 2. Characteristics of Research Areas

\begin{tabular}{|c|c|c|c|c|c|}
\hline \multirow{2}{*}{ Land Characteristics } & $\begin{array}{c}\text { Manjuto } \\
\text { Jaya }\end{array}$ & Arah Tiga & $\begin{array}{l}\text { Tanjung } \\
\text { Alai }\end{array}$ & $\begin{array}{c}\text { Pauh } \\
\text { Terenja }\end{array}$ & $\begin{array}{c}\text { Tirta } \\
\text { Makmur }\end{array}$ \\
\hline & Tf.3.1 & Af.1.2.1 & Af.1.2.2 & Tf. 2.1 & Tf. 3.1 \\
\hline \multicolumn{6}{|l|}{ Temperature (tc) } \\
\hline Temperature $\left({ }^{\circ} \mathrm{C}\right)$ & 26 & 26 & 26 & 26 & 26 \\
\hline \multicolumn{6}{|c|}{ Availability of water (wa) } \\
\hline Humidity (\%) & 83 & 83 & 83 & 83 & 83 \\
\hline \multicolumn{6}{|l|}{ Rooting medium (rc) } \\
\hline Drainage & Moderate & Fine & Moderate & Fine & Moderate \\
\hline Textur & (S) & (Ah) & (H) & (Ah) & (S) \\
\hline Soil depth $(\mathrm{cm})$ & 120 & 110 & 100 & 150 & 80 \\
\hline \multicolumn{6}{|l|}{ Nutrient retention (r) } \\
\hline $\mathrm{CEC}(\mathrm{cmol})$ & $19,1(\mathrm{~S})$ & $23,3(\mathrm{~S})$ & $18,1(\mathrm{~S})$ & $21,4(\mathrm{~S})$ & $20,3(\mathrm{~S})$ \\
\hline Base saturation (\%) & 16,17 (SR) & $19,27(\mathrm{SR})$ & 12,04 (SR) & $\begin{array}{c}17,03 \\
\text { (SR) }\end{array}$ & $12,61(\mathrm{SR})$ \\
\hline $\mathrm{pH} \mathrm{H}_{2} \mathrm{O}$ & $4.62(\mathrm{M})$ & $4.78(\mathrm{M})$ & $4.80(\mathrm{M})$ & $\begin{array}{c}5.79 \\
(\mathrm{AM})\end{array}$ & $4.66(\mathrm{M})$ \\
\hline C-organic (\%) & $3.32(\mathrm{~T})$ & $3.81(\mathrm{~T})$ & $2.88(\mathrm{~S})$ & $3.64(\mathrm{~T})$ & $3.67(\mathrm{~T})$ \\
\hline \multicolumn{6}{|l|}{ Nutrient available (n) } \\
\hline $\mathrm{N}$ total $(\%)$ & $0.35(\mathrm{~S})$ & $0.43(\mathrm{~S})$ & $0.10(\mathrm{R})$ & $0.37(\mathrm{~S})$ & $0.38(\mathrm{~S})$ \\
\hline $\mathrm{P}_{2} \mathrm{O}_{5}(\mathrm{ppm})$ & $10,11(\mathrm{R})$ & $13,10(\mathrm{R})$ & $8.69(\mathrm{SR})$ & $\begin{array}{l}8,89 \\
\text { (SR) }\end{array}$ & $10,08(\mathrm{R})$ \\
\hline $\mathrm{K}_{2} \mathrm{O}(\mathrm{mg} / 100 \mathrm{~g})$ & $0,37(\mathrm{R})$ & $0.49(\mathrm{~S})$ & $0.34(\mathrm{R})$ & $0.39(\mathrm{R})$ & $0,42(\mathrm{~S})$ \\
\hline \multicolumn{6}{|l|}{ Landslide hazard (eh) } \\
\hline Slope (\%) & $0-3 \%$ & $0-3 \%$ & $0-3 \%$ & $0-3 \%$ & $0-3 \%$ \\
\hline
\end{tabular}

The characteristics of the land at the soil sampling locations in the Lubuk Pinang District, Air Muntungo District, and XIV District for paddy fields are presented in Table 1 . The $\mathrm{pH}$ value of the soil in the study area varied from 4.62 (slightly acidic) to 5.79 (acidic). The value of $\mathrm{P}_{2} \mathrm{O}_{5}, \mathrm{~K}_{2} \mathrm{O}$ at the research location is on average low to moderate. This is due to the depletion of nutrients due to the old oil palm vegetation. The Corganic value was classified as moderate to high. The Ntotal value is moderate, while the base saturation value is low. The land characteristics of the studied area can be seen in Table 2.

Determination of the class of land suitability for paddy fields based on data values at a depth of $0-20 \mathrm{~cm}$ assuming that rice paddy plants have shallow rooting.

From the results of the research, the limiting factors of land suitability for rice paddy plants at each observation point conducted have the same limiting factors namely $\mathrm{P}_{2} \mathrm{O}_{5}, \mathrm{~K}_{2} \mathrm{O}$, and Base Saturation. To overcome this it is necessary to do calcification and fertilization to increase the nutrients $\mathrm{P}$ and $\mathrm{K}$. Thus the suitability of the land becomes very appropriate (S1) of the marginal appropriate class (S3).

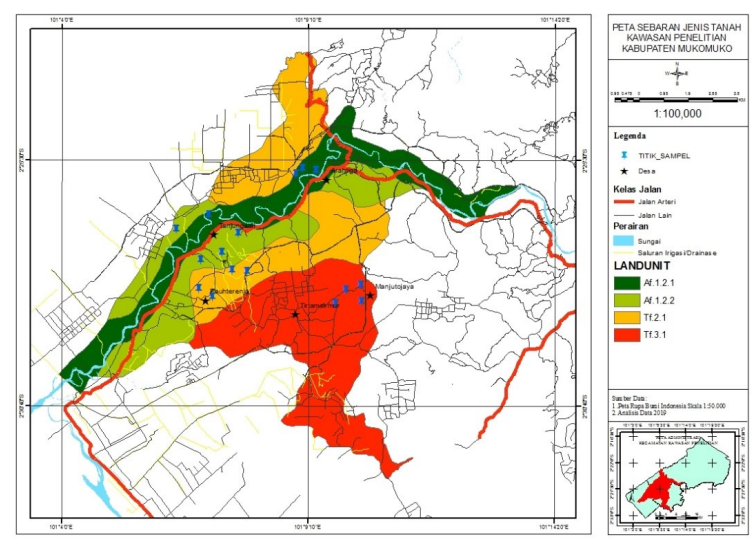

Figure 4. Distribution of soil types

$\mathrm{P}_{2} \mathrm{O}_{5}$ limiting factors of soil can be improved with a low level of management that is by fertilizing according to the needs of plants, so ideally needed the addition of fertilizer to add nutrients in the soil. Thus the suitability of the land for phosphate can be quite appropriate (S2) of the marginal appropriate class (S3).

Alkaline saturation is one of the indicators of soil chemical fertility. Fertile soil is soil with high alkaline saturation because there has not been serious soil washing. On the contrary, soil with low alkaline saturation indicates that the soil is acidic thus inhibiting the absorption of nutrients by the roots of plants (Indranada, 1986). Base Saturation and $\mathrm{CEC}$ at the research site are relatively low so it needs calcification.

\begin{tabular}{cccccc} 
Table 3. Land Suitability For Rice Paddy in Mukomuko Regency \\
\hline $\begin{array}{c}\text { Land } \\
\text { unit }\end{array}$ & \multicolumn{2}{c}{ Land Suitability } & & Repair steps & \multicolumn{2}{c}{ Wide Expanse } \\
\cline { 2 - 3 } \cline { 5 - 6 } & Actual & Potensial & & ha & $\%$ \\
\hline Af.1.2.1 & S3nr & S1 & Calcification and Fertilization & 42,68 & 17,16 \\
Af.1.2.2 & S3nr & S1 & Calcification and Fertilization & 56,65 & 22,77 \\
Tf.2.1 & S3nr & S1 & Calcification and Fertilization & 60,15 & 24,18 \\
Tf.3.1 & S3nr & S1 & Calcification and Fertilization & 89,30 & 35,90 \\
\hline \multicolumn{7}{c}{ Total } & $\mathbf{2 4 8 , 7 8}$ & $\mathbf{1 0 0 , 0 0}$
\end{tabular}

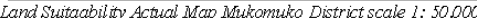

$\mathrm{S} 1=$ very suitable, $\mathrm{S} 2=$ moderate suitable, $\mathrm{r}=$ nutrient retention, $\mathrm{n}=$ nutrient av ailable

In the limiting factor, $\mathrm{K}_{2} \mathrm{O}$ soil can be improved with a moderate to the high level of management that is by fertilizing according to the needs of plants. The estimated need for $\mathrm{K}_{2} \mathrm{O}$ rice paddy plants for the criteria is very appropriate as much as $0.6 \mathrm{me} 100 \mathrm{~g}^{-1}$ while the availability of $\mathrm{K}_{2} \mathrm{O}$ available at the time of the study is 0.6 $-0.16 \mathrm{me} 100 \mathrm{~g}^{-1}$. Then it is necessary to increase potassium to meet the needs of microbes and restore potassium loss. Thus the suitability for potassium can be highly appropriate (S1) of the marginal corresponding class (S3).

Soil with somewhat hampered drainage is suitable for rice field crops. The importance of drainage in rice fields is related to the supply of oxygen (aeration). Surface water containing a lot of oxygen can enter the soil through vertical collation. Greenland (1985) suggests 
that land that has a drainage class is very hampered is also not suitable to be used as rice fields because although rice fields grow well in inundated conditions, drainage at a certain level is still very necessary.

Based on laboratory results obtained the texture class of each unit of land with dominant clay on each unit of land. So that the smaller the soil particles (clay) then the binding of soil fractions of organic matter will be high that can make the soil fertile or able to provide organic material for rice plants in each unit of land. According to Djaenuddin et al. (2003), the class of land suitability for rice plants on the texture of soil S1 among others: Clay (Clay), SC (Sandy Clay), SiCL (Silt Clay), CL (Clay Loam), and SCL (Sandy Clay Loam). Thus, most of the land units are classified as S1 class (very suitable) for rice plants.

From the results of GIS analysis assessment of the conformity of semi detailed level land for rice paddy plants in Lubuk Pinang Subdistrict, Manjuto Water Subdistrict, XIV Koto Subdistrict Mukomuko District presented in Table 3.

One way to increase the $\mathrm{pH}$ of the sour soil is by calcification. Department of Agriculture RI and Soil Research Center provides a way to calculate the dose of agricultural lime to increase the $\mathrm{pH}$ of sour soil, namely: - 2 tons of agricultural lime/ha to increase soil $\mathrm{pH}$ by 1 point. Soil $\mathrm{pH}$ suitable for rice paddy plants is $5-7$. While the average soil $\mathrm{pH}$ in each land unit of this study is 4.93 (sour), thus it takes dolomite (agricultural lime) to increase the $\mathrm{pH}$ of the soil to 6 needed as much as 2.14 tons of dolomite $\mathrm{ha}^{-1}$.

Land use at the research site is dominated by oil palm plantations that will be converted into rice fields with a total area of 248.78 ha. With oil palm plantations that have flat land and will be converted into rice fields, the government of Mukomuko Regency, especially the Kaabupaten Mukomuko Agriculture Office, is expanding the rice fields to increase rice production and to meet the food needs of Mukomuko people, especially in research areas.

On land that has limiting factors, improvements can be made presented in Table 3. Against some barriers can not be made improvements on the scale of farming, for example limiting the quality of the media rooting land caused by the texture of the soil. Several other barriers can be made repair efforts.

Limiting the quality of nutrient retention land $(\mathrm{r})$, and nutrients available (n) due to low $\mathrm{P}, \mathrm{K}$, and base saturation, can be improved through the provision of lime and fertilizer, by the characteristics of the land that is limiting. The improvement effort can be declared as an effort to intensify rice fields. With improvements, some classes of land suitability can be upgraded from S3 to S2 or from S2 to S1.

The use of fertilizer by the needs of plants is the most important factor in improving rice productivity. Rice production in Mukomuko Regency averaged 6-7 tons ha ${ }^{-1}$ not spared by the provision of balanced fertilizer, at a high productivity level (6-7 tons ha $\left.{ }^{-1}\right)$ urea required $300-400 \mathrm{~kg}$ ha ${ }^{-1}$, if rice plants in a location produce grain as much as 3 tons $\mathrm{ha}^{-1}$ without fertilization $\mathrm{N}$, while the target yield is 6 tons $\mathrm{ha}^{-1}$, then the additional urea fertilizer required is about $325 \mathrm{~kg}$ without the use of BWD and $250 \mathrm{~kg}$ with BWD. As a result, Nasution's research (2014) showed that high production would not have been possible if it had not been accompanied by balanced fertilization.

Nutrient status at the research site has criteria ranging from very low to low and has a very large area at the research site. Therefore, the research site recommended doses of fertilization to meet the availability of nutrients $\mathrm{P}$, and $\mathrm{K}$. Recommended doses of fertilization to meet the availability of nutrients $\mathrm{P}$, and $\mathrm{K}$ is given in the form of fertilizer SP36 and $\mathrm{KCl}$. As for the dose of each fertilizer SP36, and $\mathrm{KCl}$ in each Land Unit in the research area presented in Table 4.

Table 4. Recommendations for Fertilization for Rice Paddy Research Area Mukomuko District

\begin{tabular}{|c|c|c|c|c|c|c|}
\hline \multicolumn{7}{|c|}{$\begin{array}{c}\text { Recommendations for Phosphorus in Paddy Rice Plants and Potassium Fertilization in Paddy Rice Plants with and Without Rice Straw } \\
\text { Organic Material }\end{array}$} \\
\hline \multirow{2}{*}{ Land Unit } & \multirow{2}{*}{ Village } & \multirow{2}{*}{$\begin{array}{l}\text { Nutrient available } \mathrm{P}_{2} \mathrm{O}_{5} \\
\quad\left(\mathrm{mg} 100 \mathrm{~g}^{-1}\right)\end{array}$} & \multirow{2}{*}{$\begin{array}{c}\text { Nutrient available } \mathrm{K}_{2} \mathrm{O} \\
\left(\mathrm{mg} / 100 \mathrm{~g}^{-1}\right)\end{array}$} & \multirow{2}{*}{$\begin{array}{l}\text { Recommended } \\
\text { fertilization } \\
\text { dosages (kg SP. } \\
\left.\quad 36 \mathrm{ha}^{-1}\right)\end{array}$} & \multicolumn{2}{|c|}{$\begin{array}{l}\text { Recommended fertilization dosages } \mathrm{K} \\
\left(\mathrm{kg} \mathrm{KCl} \mathrm{ha}^{-1}\right) \\
\end{array}$} \\
\hline & & & & & +Straw & -Straw \\
\hline Af.1.2.1 & Arah Tiga & $13,1(\mathrm{R})$ & $0,49(\mathrm{R})$ & 100 & $50 \mathrm{~kg} \mathrm{KCl}+12$ ton straw & 100 \\
\hline Af.1.2.2 & Tanjung Alai & $8,69(\mathrm{R})$ & $0,34(\mathrm{R})$ & 100 & $50 \mathrm{~kg} \mathrm{KCl}+12$ ton straw & 100 \\
\hline Tf.2.1 & Pauh Terenja & $8,89 \mathrm{R})$ & $0,39(\mathrm{R})$ & 100 & $50 \mathrm{~kg} \mathrm{KCl}+12$ ton straw & 100 \\
\hline \multirow{2}{*}{ Tf.3.1 } & Manjuto Jaya & $10,11(\mathrm{R})$ & $0,37(\mathrm{R})$ & 100 & $50 \mathrm{~kg} \mathrm{KCl}+12$ ton straw & 100 \\
\hline & Tirta Makmur & $10,08(\mathrm{R})$ & $0,42(\mathrm{R})$ & 100 & $50 \mathrm{~kg} \mathrm{KCl}+12$ ton straw & 100 \\
\hline
\end{tabular}




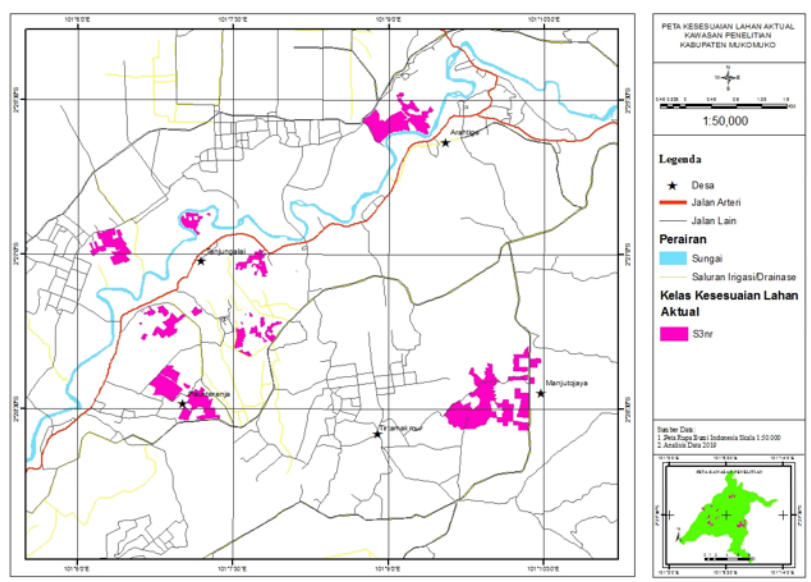

Figure 5. Actual Land Suitability Map

\section{CONCLUSION}

The research area can be divided into 4 land units. The area of land unit Af.1.2.1 is 42.68 hectares, the area of land unit Af.1.2.2 is 56.65 hectares, the area of land unit Tf.2.1 is 60.15 hectares, the area of the unit land Tf.3.1 covering an area of $89.30 \mathrm{ha}$.

The actual land suitability of the research area is S3nr for all land units. Where the land suitability class has a limiting factor that can be improved for lowland rice plants, so that the resulting potential land suitability from according to marginal (S3) to very suitable (S1).

With improved land suitability and highly suitable land suitability (S1), rice fields can be expanded in the Mukomuko Regency to support food needs and increase rice production in Mukomuko Regency. If the advantages of farming are prioritized, the lowland rice cultivation activities in Mukomuko Regency are still considered profitable, however, soil management in the Mukomuko Regency area must be improved, especially the provision of $\mathrm{P}$ and $\mathrm{K}$ nutrients.

\section{References}

Arsyad, S. \& Rustiadi, E. (2008). Penyelamatan Tanah Air dan Lingkungan. Crestpen Press dan Yayasan Obor Indonesia, Jakarta.

Badan Penyuluh Pertanian. (2012). Program Penyuluh Pertanian, Perikanan, Perkebunan dan Kehutanan Kecamatan Padang Batung, Padang Batung.

Badan Pusat Statistik. (2013). Kabupaten Mukomuko Dalam Angka, Mukomuko.

BWS Sumatera VII. (2013). Internal Report Not published. Laporan Monitoring Debit di Stasiun Pengukuran Debit di Hulu dan Hilir Sungai Air Bengkulu Periode Januari - Desember 2013. BWS Sumatera VII, Bengkulu.

Djaenudin, D., Marwan, H., Subagyo, H. \& Hidayat, A. (2003). Petunjuk Teknis untuk Komoditas Pertanian. Edisi Pertama tahun 2003, ISBN 979-9474 -25-6. Balai Penelitian Tanah, Pusat Penelitian dan Pengembangan Tanah dan Agroklimat, Bogor, Indonesia.

Djaenudin, D., Marwan, H., Subagjo, H. \& Hidayat, A. (2011). Petunjuk Teknis Evaluasi Lahan Untuk Komoditas Pertanian. Balai Besar Litbang Sumberdaya Lahan Pertanian, Badan Litbang Pertanian, Bogor.

Hamdan. (2013). Analisis Efisiensi Penggunaan Faktor Produksi pada Usahatani Padi Sawah di Bengkulu. Balai Pengkaji Teknologi Pertanian, Bengkulu.

Nasution, E. H. (2014). Pengaruh Pemberian Pupuk N, P, $\mathrm{K}$, dan Mg Berdasarkan Unsur Hara Tanah yang Diserap untuk Meningkatkan Produksi Padi Sawah (Oryza sativa). Skripsi. Prodi Agroteknologi, Fakultas Pertanian Universitas Graha Nusantara Padangsidempuan, Padangsidempuan.

Sulaeman, Suparto, \& Eviati. (2005). Analisis Kimia Tanah, Tanaman, Air, dan Pupuk.Bogor. Balai Penelitian Tanah. http://balittanah.litbang. deptan. go.id. 